\title{
Three new legumes endemic to the Marañón Valley, Perú
}

\author{
G. P. Lewis ${ }^{1}$, C. E. Hughes ${ }^{2,3}$, A. Daza Yomona ${ }^{4}$, J. Solange Sotuyo ${ }^{5}$ \& M. F. Simon ${ }^{2,6}$
}

Summary. Two new species of legume, Caesalpinia celendiniana and Mimosa lamolina and one new variety, Caesalpinia pluviosa var. maraniona, from the inter-Andean Río Marañón Valley in northern Perú are described and illustrated. These add to the already impressive tally of endemics known from the seasonally dry tropical forests of the Río Marañón Valley, which apparently far exceeds the endemic plant diversity from other nearby inter-Andean dry valleys in Perú and southern Ecuador.

Key Words. Caesalpinia, Caesalpinioideae, endemic, Fabaceae, Leguminosae, Mimosa, Mimosoideae, Perú.

\section{Introduction}

Amongst the seasonally dry tropical forests of the inter-Andean valleys of Perú and adjacent countries, the Río Marañón Valley apparently harbours exceptionally high numbers of narrowly restricted endemic plants (Hensold 1999; Linares-Palomino 2006; Linares-Palomino \& Pennington 2007; http://rbgweb2.rbge.org.uk/dryforest/database.htm). Furthermore, many of these Marañón Valley endemic species have been discovered and described only within the last decade (e.g. Barneby 1998; Hughes et al. 2003, 2004; Hughes 2005; Pendry 2004), suggesting that the valley remains under-collected and poorly known botanically. The three additional endemic legumes described here add to this already impressive tally and to the evidence that the upper Río Marañón Valley forms an important and apparently under-collected hotspot of dry inter-Andean valley plant diversity. These new taxa also contribute to the growing list of genera, especially of legumes and cacti (e.g. Armatocereus Backeb., Browningia Britton \& Rose, Caesalpinia L., Calliandra Benth., Coursetia DC., Espostoa Britton \& Rose, Jacquemontia Choisy., Mimosa L., Ruprechtia C. A. Mey. and Senna Mill.), that have multiple congeneric Marañón endemics (Hughes 2005).

Two of the new taxa described here are placed in the genus Caesalpinia despite the fact that Caesalpinia sensu lato is known to be polyphyletic (Lewis \& Schrire 1995; Simpson \& Miao 1997; Lewis 1998;
Simpson 1998, 1999; Simpson \& Lewis 2003; Simpson et al. 2003; Lewis 2005; Bruneau et al. 2008; Sotuyo et al. unpublished). A number of genera, traditionally placed in synonymy under Caesalpinia s.l., were reinstated as distinct by Lewis (2005), although not all necessary combinations have yet been published for the suite of species now considered to belong to each of the segregate genera. Sotuyo et al. (unpublished) included Hughes 2210 et al. (C. celendiniana) and Hughes 2215 et al. (C. pluviosa var. maraniona) in a number of phylogenetic analyses using molecular data. In all of those analyses $C$. celendiniana is resolved as sister to C. trichocarpa, and C. pluviosa var. maraniona as related to other described varieties of C. pluviosa and also to C. gaumeri. Lewis (1998) published a revision of the Poincianella-Erythrostemon group of Caesalpinia sensu lato and both Poincianella and Erythrostemon were reinstated as genera by Lewis (2005). However, recent unpublished studies by Sotuyo et al. have confirmed the earlier findings of Simpson et al. (2003) which showed that both Poincianella and Erythrostemon are not fully supported as monophyletic. Of relevance here is the finding that C. pluviosa (a South American species) and $C$. eriostachys (from Central America and Mexico) are sister species that together do not group with other species of Poincianella, and that the relationship of $C$. trichocarpa remains equivocal, with uncertain affinities to the closely allied Pomaria, Poincianella and Erythrostemon. Because the

\footnotetext{
Accepted for publication June 2010.

1 Herbarium, Library, Art and Archives, Royal Botanic Gardens, Kew, Richmond, Surrey, TW9 3AB, UK.

2 Department of Plant Sciences, University of Oxford, South Parks Road, Oxford, OX1 3RB, UK.

3 Present Address: Institute for Systematic Botany, Zollikerstrasse 107, 8008 Zurich, Switzerland.

4 Herbario MOL, Departamento de Manejo Forestal, Facultad de Ciencias Forestales, Universidad Nacional Agraria La Molina, Apartado 456, La Molina, Lima, Perú.

5 Departamento de Botánica, Instituto de Biología, U.N.A.M., Circuito Exterior s/n, Ciudad Universitaria, Copilco, Coyoacán, A.P. $70-367$ México, Distrito Federal, C.P. 04510

6 Present Address: Embrapa, PqEB s/n., Brasilia-DF, 70770-901 Brazil.
} 
taxonomic position of the sister species of the two new taxa described here are not yet fully resolved, we consider it more appropriate to describe the new taxa in the genus Caesalpinia sensu lato, rather than in a named segregate genus. We recognise, however, that, at a future date, both taxa are likely to change genus.

Caesalpinia celendiniana G. P. Lewis $\mathcal{E}$ C. E. Hughes sp. nov. C. trichocarpae affinis sed surculis angulosis vel tetragonis (non teretibus), stipulis lanceolatis non ovatis $5 \mathrm{~mm}$ non $2-3 \mathrm{~mm}$ tantum longis, inflorescentiis $24 \mathrm{~cm}$ usque plusquam $40 \mathrm{~cm}$ (non $3-6 \mathrm{~cm}$ tantum) longis multifloris non flores minus quam 30 tantum ferentibus, petalis c. $6 \mathrm{~mm}$ (non ut minimum $8 \mathrm{~mm}$ ) longis et staminibus c. $5 \mathrm{~mm}$ (non $7.5-9 \mathrm{~mm}$ ) longis differt. Typus: Perú, Cajamarca, Celendín, Río Marañón Valley, km 47 rd Celendín to Balsas on slopes on $\mathrm{W}$ side of the valley, 22 April 2002, fl. \& fr., Hughes 2210 et al. (holotypus K!; isotypi FHO!, MOL!).

\section{http://www.ipni.org/urn:lsid:ipni.org:names:77105277-1}

Erect herb to brittle multi-stemmed, sometimes scrambling, shrub, 0.7 - $2 \mathrm{~m}$ tall, woody at the base from which arise slender, green, strongly angular to tetragonal shoots that die back and resprout annually, bark of older stems smooth, grey-brown, slash greenish, stems densely covered in maroon glandular hairs and a fine puberulous, white indumentum. Stipules lanceolate, $5 \times$ $1.5 \mathrm{~mm}$, apex needle shaped to filiform, one margin falcate, the other unevenly ragged-dentate, the outer surface with a patent white pubescent indumentum mixed with maroon stalked glandular trichomes. Leaves bipinnate, spirally arranged, petiole $1.8-3.5 \mathrm{~cm}$ long, leaf rachis $3-6 \mathrm{~cm}$ long, covered in maroon glandular hairs, pinnae in $2-3$ pairs per leaf, usually ending in a single pinna, but this sometimes lacking, leaflets in $4-7$ pairs per pinna (usually only $3-4$ pairs on the terminal pinnae), distal leaflets of the terminal pinnae obovate, $5-11 \times 3-5 \mathrm{~mm}$, their apices shallowly emarginate, median leaflets of the median pinnae oblong-elliptic, $6-12 \times 3-6.5 \mathrm{~mm}$, all leaflets somewhat fleshy, upper surface glabrous, lower surface glabrous or with a sparse pubescence at the base of the midvein to half way along it, the margins sometimes sparsely ciliate with white hairs, only the midvein evident, some leaflets, usually the basal ones, on each pinna with a crenate, or partially crenate margin, with sessile maroon (drying black) glands (of varying number per leaflet) in the shallow marginal sinuses between the crenations, either along the basal third of the margin or all way round the leaflet circumference, together with the occasional sessile gland in shallow depressions on the leaflet blade lower surface, and usually a single gland at the apex of the midvein. Inflorescence a long, lax, terminal or axillary, erect, many-flowered raceme, c. $24-41.5 \mathrm{~cm}$ long, the axis with a fine puberulous indumentum of patent white hairs intermixed with stipitate maroon glandular trichomes. Flower buds globose, the lower sepal \pm cucullate and slightly longer than the other four, all sepals densely pubescent with white patent hairs; pedicel of open flower $8 \mathrm{~mm}$ long, articulated $1.5 \mathrm{~mm}$ below the calyx, pubescent with white patent hairs along its whole length, with maroon stipitate glandular trichomes intermixed, or these restricted to the point of articulation (where they are especially dense) and below; bracts lanceolate, acuminate, $3.5-4 \times 1-$ $1.5 \mathrm{~mm}$, the margin fimbriate-dentate, the fimbriae gland-tipped or not, the outer surface densely pubescent with white patent hairs and maroon stipitate glands intermixed. Calyx pale green flushed pinkish red, pubescent, with or without glandular trichomes intermixed, calyx lobes $6-6.5 \mathrm{~mm}$ long, very slightly fimbriate and glandular near the apex, the margin ciliate with white hairs, the inner surface glabrous, the outer surface moderately puberulous with white hairs and short-stalked to almost sessile maroon glands intermixed. Corolla orange-yellow with red markings, the standard petal fringed brilliant red along the upper part of the margin, the blade broadly ovate with an acute apex, $6 \times 4 \mathrm{~mm}$ (including a $1 \mathrm{~mm}$ long broad open claw), inner surface of claw moderately to densely pubescent, outer surface of whole petal glabrous and eglandular except for a pubescent claw base; upper lateral petals yellowish orange at base, reddish orange at apex, obovate, $6 \times 4 \mathrm{~mm}$, glabrous, eglandular, tapering towards a very short, $<0.5 \mathrm{~mm}$ pubescent claw; lower lateral petals slightly smaller than the upper laterals, $6 \times 3 \mathrm{~mm}$, otherwise identical. Stamen filaments green tinged pink, c. $5 \mathrm{~mm}$ long, pubescent along the lower $1 / 2$ to $2 / 3$, especially so near the base, anthers $1 \times 0.5 \mathrm{~mm}$. Ovary and base of style densely covered in stipitate glandular trichomes, these mostly maroon in colour, but those of the central portion of the ovary white to ochre, a few transparent to whitish simple hairs intermixed with the glands; style $1.5-$ $2 \mathrm{~mm}$ long, the apex curved upwards, pubescent almost to its apex, the stigma sublateral, chambered, without evident fringing papillae. Fruit a lunate legume, $25 \times$ $9 \mathrm{~mm}$, coriaceous, dehiscent, the apex acute (or with a persistent style forming a $5-6 \mathrm{~mm}$ long apiculum), no calyx lobes persist around the fruit base, the valves densely covered in a mixture of simple patent white hairs and gland-tipped dendritic maroon trichomes (the stalk of the gland hairy), 3 - 4-seeded. Seeds olivegreen to brownish, smooth, ovate to sub-elliptic, plump, c. $4.5-5 \times 3.5-4 \times 1 \mathrm{~mm}$. Fig. 1 .

DISTRIBUTION. Caesalpinia celendiniana, as currently known, is restricted to the area between Celendín and Balsas in the Río Marañón Valley in the Peruvian province of Celendín, Department of Cajamarca. Map 1. 


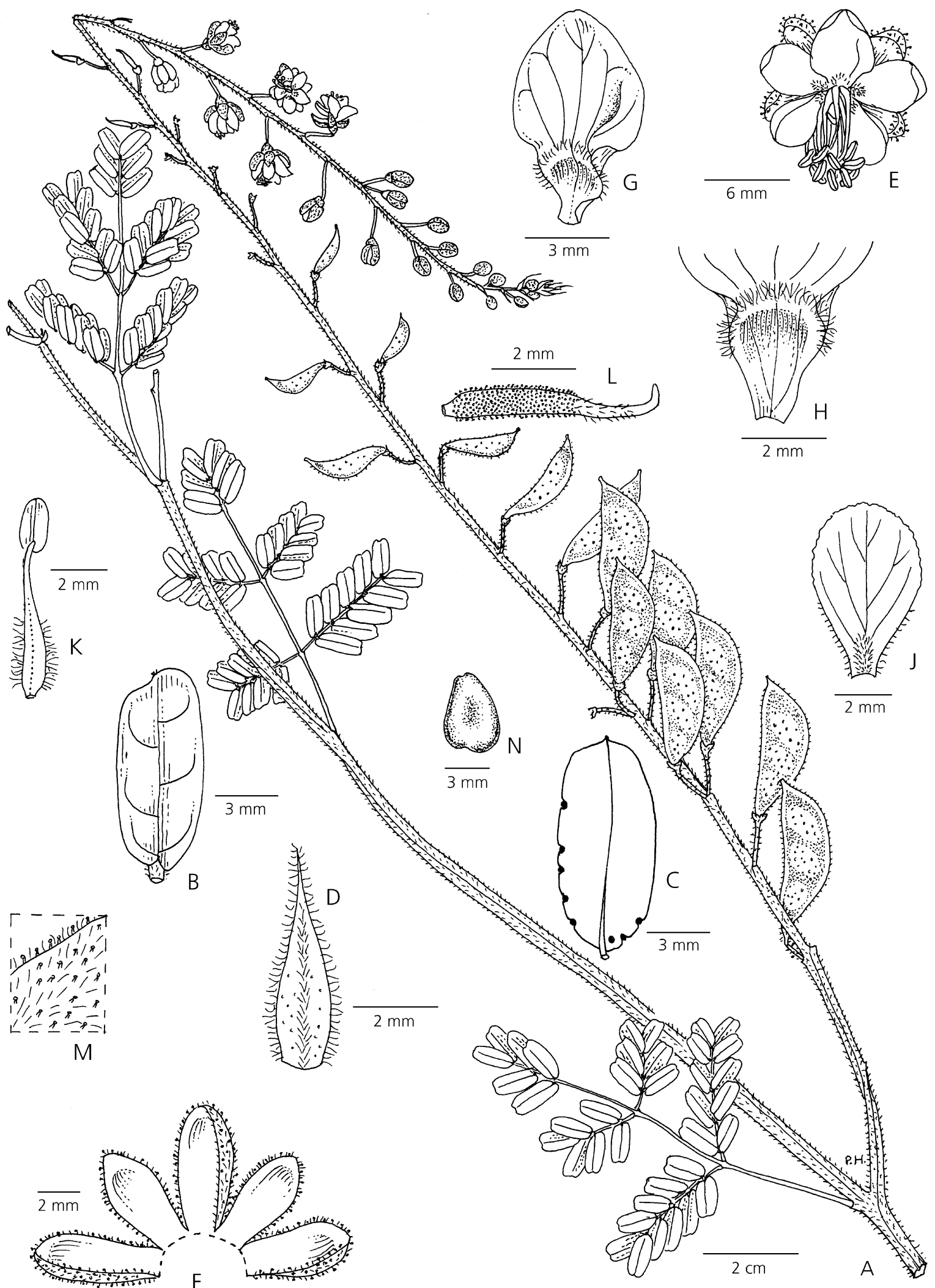

Fig. 1. Caesalpinia celendiniana. A habit; B leaflet from mid-pinna, upper surface; C leaflet from basal position on pinna, lower surface showing glands; D bracteole; E flower; F calyx opened out; $\mathrm{G}$ standard petal inner surface; $\mathrm{H}$ standard petal claw inner surface; J upper lateral petal; $\mathrm{K}$ stamen; L gynoecium; $\mathrm{M}$ detail of indumentum and glands on fruit surface; $\mathrm{N}$ seed. $\mathrm{C}$ from Pennington et al. 17567; all the rest from Hughes 2210 et al. DRAWN BY PAT HALLIDAY. 


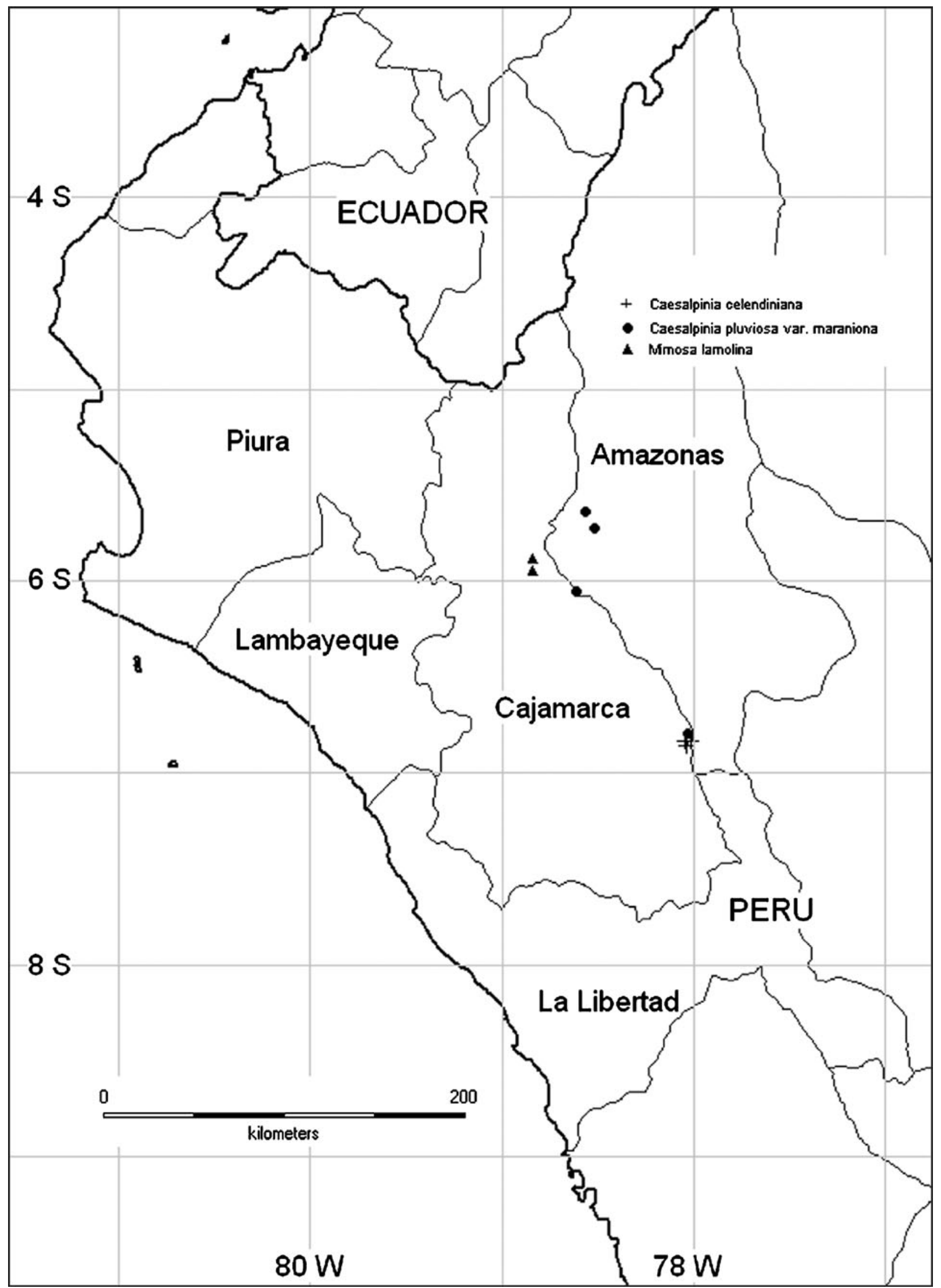

Map 1. Distributions of Caesalpinia celendiniana, Mimosa lamolina and Caesalpinia pluviosa var. maraniona in northern Perú. 
SPECIMENS EXAMINED. PERÚ. Cajamarca: Celendín, Río Marañón Valley, km 47 rd Celendín to Balsas on slopes on west side of the valley, $6^{\circ} 51^{\prime} 28^{\prime \prime} \mathrm{S}$, 78 02'33"W, 22 April 2002, fl. \& fr., Hughes 2210 et al. (holotype $\mathrm{K}$ !; isotypes $\mathrm{FHO}$ !, MOL!); Celendín to Balsas, descent to Balsas, $6^{\circ} 50^{\prime} \mathrm{S}, 78^{\circ} 01^{\prime} \mathrm{W}, 28 \mathrm{Nov}$. 2003, fl. \& fr., T. D. Pennington et al. 17567 (K!, UNALM (MOL!); Celendín, Balsas-Celendín rd, 7 $13 \mathrm{~km}$ from Balsas, Río Marañón Valley, 650'S, $78^{\circ} 03^{\prime}$ W, 24 Feb. 1984, fl., D. N. Smith 6182 (NY!, photo K!).

HABITAT. Locally common in dry thorn scrub and tropical dry forest; $1250-1600 \mathrm{~m}$. Associated taxa include Leucaena trichodes (Jacq.) Benth., Pithecellobium excelsum (Kunth) Benth., Machaerium sp., Coursetia cajamarcana Lavin, Mimosa incarum Barneby, M. ctenodes Barneby, Indigofera sp., Parkinsonia praecox (Ruiz \& Pav.) Hawkins (all in the Leguminosae), Eriotheca sp. (Bombacaceae), Saccellium sp. (Boraginaceae) and species of columnar cactus.

CONSERVATION STATUS. Caesalpinia celendiniana is known from just a small area on the west side of the Río Marañón above Balsas and, as currently known, is undoubtedly globally rare and is provisionally assigned a conservation rating of Critically Endangered (CR b1). However, given the inaccessibility of the Río Marañón valley slopes upstream and downstream of the bridge at Balsas, it remains unclear just how widespread and abundant this plant is and more precise assessment of its conservation status must await more thorough field survey.

PHENOLOGY. Known to flower and fruit from November to April.

ETYMOLOGY. The species epithet is taken from the Province of Celendín in which Caesalpinia celendiniana is currently considered to be endemic.

NOTES. Caesalpinia celendiniana is morphologically similar to C. trichocarpa in leaf formula, leaflet glands and shared fruit indumentum and this relationship is supported by phylogenetic analyses of molecular data (Sotuyo et al., unpublished) which resolve the new species and C. trichocarpa as sister taxa. C. celendiniana differs, however, in its markedly angular stems and much longer inflorescences with many more and larger flowers.

Caesalpinia pluviosa DC. var. maraniona G. P. Lewis $\mathcal{E}$ C. E. Hughes var. nov. ab omnibus ceteris varietatibus C. pluviosae characteribus variis singulariter coniunctis scilicet foliis e $2-4$ paribus pinnarum (atque pinna terminali) constantibus, pinnis e $7-11$ foliolis constantibus, staminibus $11-12 \mathrm{~mm}$ longis, pedicellis in medio vel parum infra (ad distantiam $5-7.5 \mathrm{~mm}$ infra calycem) articulatis et distributione disjunctiva differt. Typus: Perú, Cajamarca, Celendín, Marañón Valley, km 50 rd from Celendín to Leimebamba, 23
April 2002, fl. \& fr., Hughes 2215, Daza Eं Forrest (holotypus FHO!; isotypi K!, MOL!).

http://www.ipni.org/urn:lsid:ipni.org:names:77105278-1

Shrub or small, often multi-stemmed, much branched tree, $1.8-5 \mathrm{~m}$ tall, with a dense rounded crown, trunk or main stems $4 \mathrm{~cm}$ in diam., bark silvery mid greybrown, characteristically exfoliating in delicate papery vertical strips, the bark somewhat rougher on older stems, slash pale brown, inner bark green; young branches glabrous, or finely puberulous to sparsely pubescent, glabrescent, or the outer papery bark with scattered stellate white trichomes, or reddish orange glandular trichomes surrounded by simple hairs, the stems, leaf rachises and petioles with scattered pustular glands. Stipules spatulate, $8-10 \times 4-5 \mathrm{~mm}$, the outer surface sparsely puberulous, and with a scattering of dark sunken glands, the tapering base with short-stalked glands, the margin fimbriate, glandular and ciliate, caducous. Leaves bipinnate, pinnae in $2-4$ pairs per leaf, plus a single terminal pinna, the basal $1-2$ pairs alternate to subopposite, the apical pair opposite (and together with the single terminal pinna digitate); petiole $2-4 \mathrm{~cm}$ long, the basal pulvinus plump and somewhat expanded, a brown axillary perulate resting bud in the petiole axil; leaf rachis $2.5-8 \mathrm{~cm}$ long; leaflets alternate to subopposite, subsessile (the leaflet blade \pm auriculate around the upper $^{2} / 3$ of the pulvinule), sub-coriaceous, $7-11$ per pinna (each pinna with either a single terminal leaflet or a pair of leaflets), the pulvinule drying black in contrast to the yellowish midvein; distal leaflets of the terminal pinnae ovate, obovate or widely elliptic, 1.7 $3 \times 1.1-1.9 \mathrm{~cm}$, the apex rounded to shallowly retuse, the base asymmetric, the midvein sometimes falcate, the median leaflets of the lower pinnae varying in shape from sub-circular to sub-quadrangular to \pm rectangular, elliptic-rhombic or trapezoid, $1.4-2.2$ $(-2.8) \times 1-1.5(-1.8) \mathrm{cm}$, apex rounded to shallowly retuse, base obtuse to inequilaterally truncate, upper surface of all leaflets sparsely to moderately puberulous to pubescent, or glabrous, sometimes only the midvein hairy, or only the pulvinule and the base of the midvein hairy (in material from Bagua Chica), occasionally shiny, the lower surface sparsely to moderately pubescent, or glabrous, dull, the margin ciliate (on material from Bagua Chica), the midvein and secondary venation flush or slightly prominent on both surfaces, \pm brochidodromous, the reticulate tertiary venation evident on the lower surface, a dark gland at the apex of the midvein, sunken black glands within the areoles of the tertiary venation on the lower surface, and around the blade margin, the glands very obscure on the more mature coriaceous leaflets. Inflorescence a short, erect, axillary or terminal, c. 30 60 -flowered raceme held above the foliage, sometimes 
with secondary branching and thus paniculate, the rachis puberulous to pubescent to finely tomentose, with stellate-glandular trichomes intermixed (especially when young), or glabrous. Flowers yellow, the pedicel $10-15 \mathrm{~mm}$ long, articulated at or just below its middle ( $5-7.5 \mathrm{~mm}$ below the calyx), the point of articulation slightly ridged and with a concentration of pale tangerine-coloured glandular trichomes, below the articulation glandular and glabrous to finely puberulous, above glandular and pubescent or puberulous, with stellate trichomes sometimes intermixed; bracts lanceolate to ovate-lanceolate, $4-5 \times 2 \mathrm{~mm}$, densely tomentose with matted trichomes together with a few subepidermal glands; calyx bright glossy green, upper and lateral lobes $(5-) 6-7.5 \mathrm{~mm}$ long, slightly reflexed, finely puberulous on both surfaces, a few subepidermal glands evident (these appearing as oil globules), lower calyx lobe $7-8(-9) \mathrm{mm}$ long, the margin finely fimbriate, the fimbriae gland-tipped; standard petal sometimes speckled or streaked orangish red in its centre, suborbicular to broadly obovate to sub-panduriform, $11-12 \times 8-10 \mathrm{~mm}$ (including a $2.5-3 \mathrm{~mm}$ long claw), the claw apex thickened on either side forming two erect, angular, sparsely glandtipped ridges, the thickening of the claw far more pronounced than in the four lateral petals, a few subepidermal black glands embedded in the blade apex; the upper lateral petals suborbicular to elliptic or obovate, $11-12.5 \times 8-11 \mathrm{~mm}$ (including a $2.5-$ $3 \mathrm{~mm}$ long claw), the folded base of the blade running into the inrolled, thickened claw; the lower lateral petals suborbicular to elliptic-obovate, the blade asymmetric in relation to the claw position, $12-13 \times$ $8-10 \mathrm{~mm}$ (including a $2-3 \mathrm{~mm}$ long claw), the folded base of the blade running into the inrolled, thickened claw; all petals densely covered with shortstalked or sessile glandular trichomes on their outer surfaces, all with a fine reticulate network of veins, the bases of the petal claws all pubescent on the outer surface; stamen filaments green, c. $11-12 \mathrm{~mm}$ long, the basal $2 / 3$ to $3 / 4$ pubescent (the basal $1 / 4$ densely so) at least along the inner surface, an occasional short-stalked gland intermixed with the indumentum, anthers dull orangish green, $1.5-2 \times 1 \mathrm{~mm}$; ovary $6-7 \mathrm{~mm}$ long, moderately to densely puberulous to pubescent (with a mixture of short and longer hairs), with sessile to short-stalked glandular trichomes, stellate trichomes and stellate trichomes with a central stalked gland all intermixed, style c. $8 \mathrm{~mm}$ long with an indumentum as on the ovary, stigma a chamber fringed by a ring of papillae, the style apex slightly expanded directly below the stigma. Fruit an explosively dehiscent, 5 - 6-seeded woody legume, yellowish green when unripe, turning mid orange-brown at maturity, $5.8-10.5 \times 1.7-2.8 \mathrm{~cm}$, the valves glabrous with subepidermal glands sometimes erupting as glandular pustules, occasionally with transverse orange-red resinous ducts and raised woody veins, the seeds separated by sub-woody partitions. Seeds pale yellowish brown when fresh, mid brown and shiny when dry, broadly ovate to broadly elliptic, $10-16 \times$ $7.5-13 \mathrm{~mm}$. Figs $2 \& 3$.

DISTRIBUTION. Caesalpinia pluviosa var. maraniona is apparently common in the middle reaches of the upper Río Marañón Valley in northern Perú, in the Departments of Amazonas and Cajamarca. Most collections come from either the area between Celendín and Leimebamba, or from between Jaén and Bagua Chica. Map 1.

SPECIMENS EXAMINed. PERÚ. Amazonas: Prov. Bagua, $2 \mathrm{~km}$ W of Bagua Chica, W of Río Utcubamba, 19 Jan. 1964, fl., Hutchinson E् Wright 3635 (F, NY! [photo K!], UC, US, USM); Utcubamba, Marañón Valley, $\mathrm{S}$ of Cumba, 603'04"S, 78³6'41"W, 20 April 2007, fl. \& fr., Särkinen et al. 2191 (FHO!, K!, MOL, USM); Cajamarca: Celendín, Balsas, km 54 rd from Celendín to Balsas, a few $\mathrm{km} \mathrm{W}$ of Balsas in the depths of the Marañón Valley, a few $100 \mathrm{~m}$ above river, $6^{\circ} 51^{\prime} 13 " \mathrm{~S}$, $78^{\circ} 01^{\prime} 42^{\prime \prime} \mathrm{W}, 950 \mathrm{~m}, 12$ June 2001, fr., Hughes 2020 E Daza (CAS!, FHO!, K!, MOL!, NY!); Celendín, Marañón Valley, $\mathrm{km} 50 \mathrm{rd}$ from Celendín to Leimebamba, c. $4 \mathrm{~km}$ from bridge at Balsas, on $\mathrm{W}$ slopes of Marañón Valley, $6^{\circ} 51^{\prime} 14^{\prime \prime S}, 78^{\circ} 01^{\prime} 43^{\prime \prime} \mathrm{W}, 23$ April 2002, fl. \& fr., Hughes 2215, Daza E Forrest (holotype FHO!; isotypes $\mathrm{K}$ !, MOL!); c. $300 \mathrm{~m}$ from Chamaya (small village at junction of rd from Jaén with main rd OlmosBagua, by Río Marañón), up rd to Jaén, 542'83"S, 78 30 '65"W, 13 March 1998, fl., R. T. Pennington et al. 793 (E, K!, MOL); c. $300 \mathrm{~m}$ from Chamaya, up road to Jaén, 5 50 $50^{\prime} 6^{\prime \prime S}, 78^{\circ} 45^{\prime} 23^{\prime \prime W}, 1$ Nov. 2000, fl., $R$. T. Pennington et al. 954 (E, K!, MOL); c. $100 \mathrm{~m}$ from Chamaya, up road to Jaén, 550'6"S, 78º $45^{\prime} 23^{\prime \prime} \mathrm{W}, 1$ Nov. 2000, fr., R. T. Pennington et al. 955 (E, K!, MOL); c. $1 \mathrm{~km}$ from Chamaya, up road to Jaén, $5^{\circ} 49^{\prime} 42 " \mathrm{~S}$, $78^{\circ} 45^{\prime} 27^{\prime \prime} \mathrm{W}, 14$ March 2006, fl., R. T. Pennington et al. 1736 (E, K!, MOL); near Cabramayo on road BaguaOlmos, before Pucará, 6²4'26"S, 78 56 '56"W, 14 March 2006, fl. buds, R. T. Pennington et al. 1746 (E, K!, MOL); Celendín Prov., between Limón and Balsas, 16 April 1982, fr., J. G. Sánchez Vega 5182 (NY! [photo $\mathrm{K}$ !]); Celendín Prov., Balsas-Celendín rd, $1-5 \mathrm{~km}$ from Balsas, $6^{\circ} 50^{\prime} \mathrm{S}, 78^{\circ} 04^{\prime} \mathrm{W}, 23$ Feb. 1984, fr., D. N. Smith $6159(\mathrm{~K}[\times 2] !, \mathrm{MO})$.

HABITAT. In dry thorn scrub forest (this sometimes highly disturbed) and cactus forest (so called when members of the Cactaceae are dominant) on 'desert slopes' and in dry gullies of the Río Marañón Valley; c. 450 - $1160 \mathrm{~m}$. Associated plants include Acacia macracantha Humb. \& Bonpl. ex Willd., Coursetia cajamarcana, Parkinsonia praecox, Pithecellobium excelsum, Mimosa ctenodes, M. incarum, M. pectinatipinna Burkart (all Leguminosae), Browningia sp., Espostoa sp., Melocactus sp. and Rauhocereus sp. (Cactaceae), Eriotheca sp. 


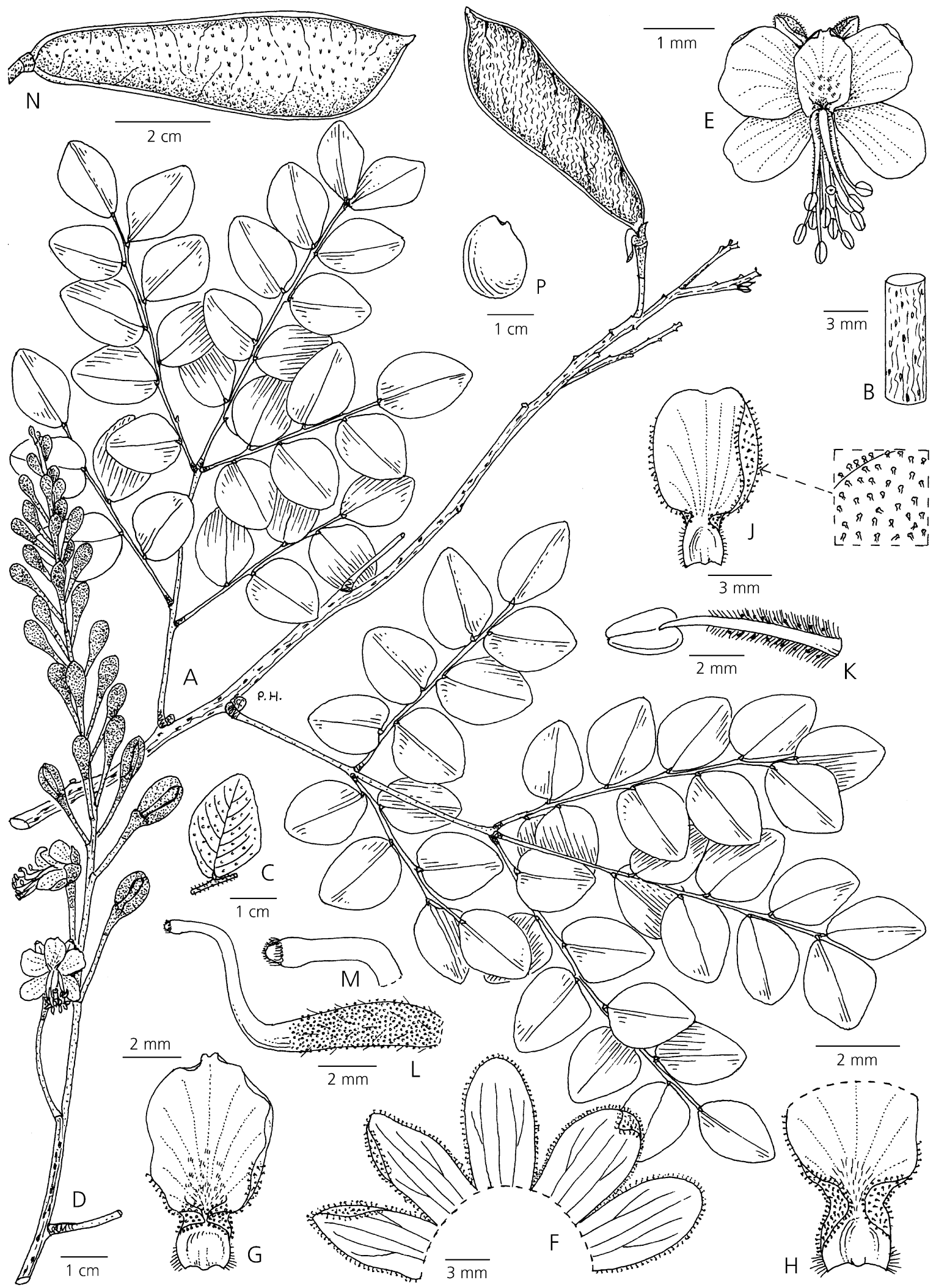

Fig. 2. Caesalpinia pluviosa var. maraniona. A habit and fruit; B section of stem; C leaflet undersurface showing glands; D inflorescence; E flower; F calyx opened out; G standard petal inner surface; $\mathrm{H}$ standard petal claw inner surface; J upper lateral petal with detail of glandular outer surface; K stamen; L gynoecium; M stigma; N fruit; P seed. A - C from Smith 6159, D - M from Hughes 2215 et al., $\mathbf{N}$ and P from Hughes 2020 \& Daza. DRAWN BY PAT HALLIDAY. 

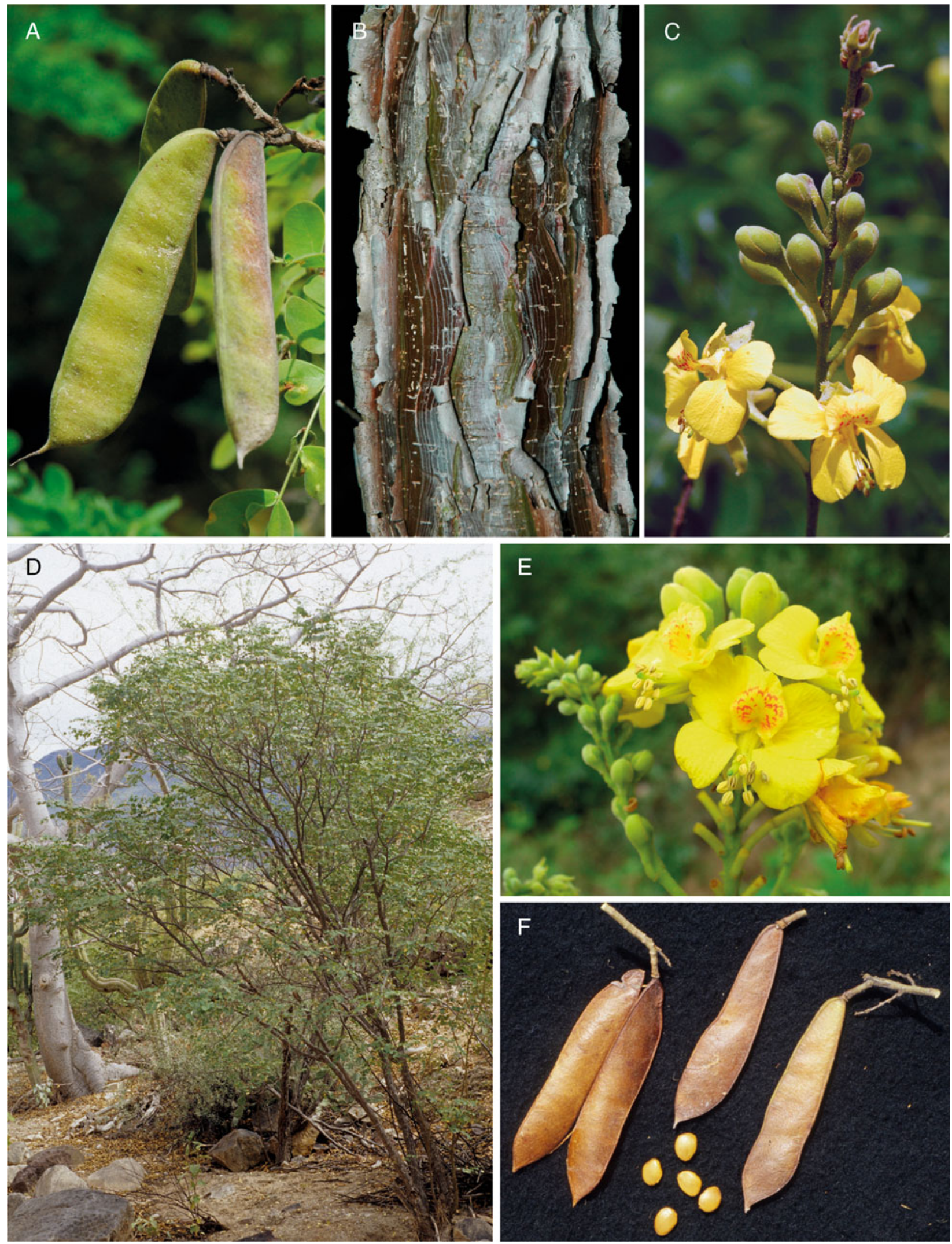

Fig. 3. Caesalpinia pluviosa var. maraniona A unripe pods; B exfoliating bark; C inflorescence and flowers; D habit - typical small treelet; E open flowers; F ripe pods and seeds. A from Särkinen et al. 2191; B - D \& F from Hughes 2020 et al.; E from Pennington 1736 et al. ALL PHOTOS C. E. HUGHES, EXCEPT E R. T. PENNINGTON. 
(Bombacaceae), Capparis sp. (Capparidaceae), and Croton sp. (Euphorbiaceae).

CONSERVATION STATUS. Although Caesalpinia pluviosa var. maraniona is restricted to the upper Río Marañón Valley of northern Perú, within the valley it occurs widely and is often abundant in secondary thorn scrub and thus, is apparently resilient to disturbance and given a conservation rating of Least Concern (LC).

PHENOLOGY. Flowering from January to April, fruiting from February to June.

ETYMOLOGY. The new variety is named after the Marañón Valley of northern Perú.

NOTES. In phylogenetic analyses of molecular data (Sotuyo et al., unpublished), Caesalpinia pluviosa var. maraniona groups with other varieties of C. pluviosa and with $C$. eriostachys from Central America and México. The close relationship of C. pluviosa (all varieties restricted to South America) with C. eriostachys was previously demonstrated in the molecular analyses of Simpson et al. (2003) and Sotuyo et al. (unpublished). The new variety maraniona is most similar in leaf formula to varieties paraensis and sanfranciscana, but neither of those taxa extend into western South America and both have pedicels that are articulated directly below to no more than $2.5 \mathrm{~mm}$ below the calyx, in contrast to the pedicel articulation at 5 $7.5 \mathrm{~mm}$ below the calyx in var. maraniona. The new taxon is also morphologically similar to C. gaumeri from Belize, the Yucatan Peninsula of México and western Cuba, and this relationship is also supported by unpublished molecular studies. C. gaumeri, however, has smooth grey bark, not the characteristic exfoliating papery bark of C. pluviosa var. maraniona. C. gaumeri also has smaller flowers with a standard petal $9-11 \times 5-7(-10) \mathrm{mm}$ (including a $3-4 \mathrm{~mm}$ long claw) in contrast to the standard $11-12 \times 8-$ $10 \mathrm{~mm}$ (including a $2.5-3 \mathrm{~mm}$ long claw) in $C$. pluviosa var. maraniona.

Mimosa lamolina C. E. Hughes $\mathcal{E} \mathcal{F}^{G}$. P. Lewis sp. nov. M. deamii B. L. Rob. habitu atque numero parium foliolorum similis etiam in arma carenti similis sed planta paene glabra setulis brevibus in petiolis pulvinulisque marginibusque foliolorum fructibusque sparse tantum dispositis ornata nec indumento e strigis robustis sistenti surculos foliaque obtegenti provisa neque craspediis strigas densas antrorsas ferentibus differt. Typus: Perú, Dept. Cajamarca, Provincia Jaén, $5 \mathrm{~km}$ E of Chiple on main road from Olmos to Jaén, 2 May 2008, Vandrot 226, Daza, Särkinen E D' ugard (holotypus K!; isotypi E!, FHO!, MOL!, NY!).

http://www.ipni.org/urn:Isid:ipni.org:names:77105279-1

Unarmed arborescent shrub, multi-stemmed from the base, but otherwise sparsely branched to $2-3 \mathrm{~m}$ tall with an irregular spreading crown, the capitula on extended efoliate pseudoracemes exserted well beyond youngest developing leaves. The whole plant more or less glabrous apart from scattered, short, $1-2$ $(-3) \mathrm{mm}$ setulae on petioles, pulvinules and margins of leaflets and fruits. Stipules, narrowly triangular, slightly incurved at tip and along lateral margins, $11-12 \times 25-40(-55) \mathrm{mm}$, with $3-5$ prominent and robust longitudinal ribs on abaxial surface, these virtually covering the surface and with scattered short setulae on margins near the base, persistent, the blades gradually disintegrating to leave just the longitudinal ribs which remain like clusters of pale setae. Leaves bipinnate, consistently 1 -jugate, the petioles slender, deeply grooved, 18 - $30 \mathrm{~mm}$ long, borne on slightly swollen $1 \mathrm{~mm}$ long pulvini, and ending in a short pointed mucro, the pinnae strictly held at $120^{\circ}$ to the petiole, the pinnular rachis of longer fully developed leaves to $5 \mathrm{~cm}$, also deeply grooved and ending in a short pointed mucro. Leaflets 5 - 6 pairs, $4.5-5.5 \mathrm{~mm}$ apart on knobbly petiolules with scattered setulae and a pair of short $1.4 \mathrm{~mm}$ long paraphyllidia at base of pinnae. Larger leaflets $22 \times 10$ (-11) mm, oblong, obtuse at apex, asymmetric at base, the terminal leaflets obovate with rounded apices and more strongly asymmetric, glabrous apart from short $2-3 \mathrm{~mm}$ stramineous setulae on margins, shorter 1 $1.5 \mathrm{~mm}$ stramineous appressed setulae scattered on underside of leaflets, and minute whitish puberulence on upper leaflet surfaces. Primary venation palmate-pinnate, brochidodromous with $3-5$ primary veins radiating from the base, secondary venation weakly percurrent, all venation prominent on both surfaces. Flowers sessile on capitula, these globose and cone-like with weakly exserted bracts in early bud, becoming moriform as capitula expand and weakly ellipsoid at anthesis, on slender 18 $20(-25) \mathrm{mm}$ peduncles, these arranged in fascicles of $2-4$ at nodes on efoliate shoots exserted well beyond the young developing leaves. Floral bracts spathulate to $1 \mathrm{~mm}$, ciliolate at tips. Calyx very reduced to a $0.5 \mathrm{~mm}$ diminutive campanulate ring. Flowers haplostemonous, the corolla 4 merous, the petals to $2.5 \mathrm{~mm}$ long, 1-nerved, glabrous, pale whitish green, the lobe tips incurved, stamens 4, these $9-9.5 \mathrm{~mm}$ long, cream-white. Fruits sessile or nearly so, in clusters of $2-5$ per capitulum, linear oblong, the margins slightly constricted between seed chambers, strongly plano-compressed, the apex long apiculate, $27-34 \times 6-7 \mathrm{~mm}$, including the $5 \mathrm{~mm}$ long apiculum, with scattered pale stramineous forward-pointing $1-1.5 \mathrm{~mm}$ setulae on margins, otherwise glabrous, green tinged maroon when unripe, turning reddish-brown when ripe, 3 - 4 seeds per pod, the pods breaking up into one-seeded articles to leave a persistent replum. Mature seeds not seen. Fig. 4. 


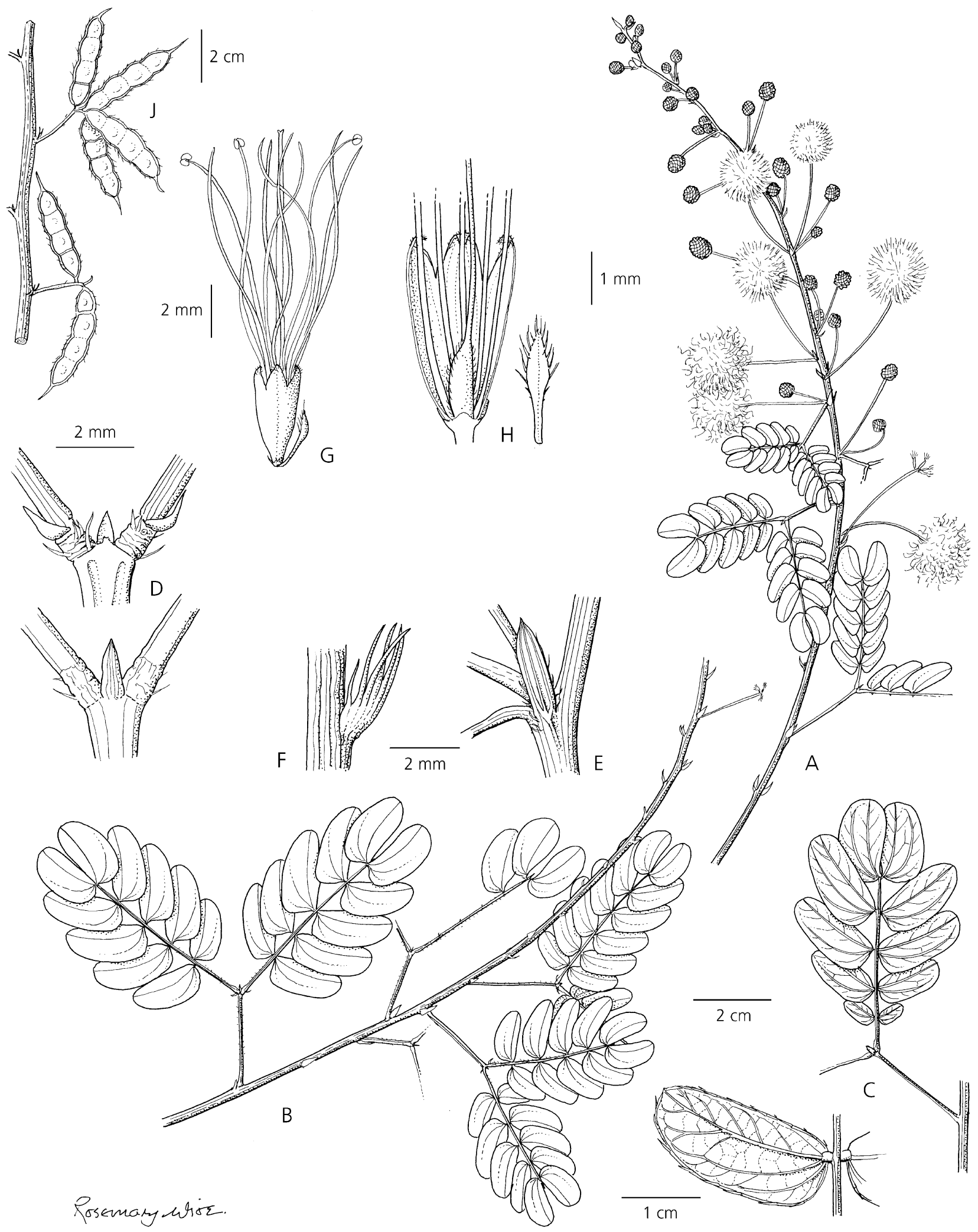

Fig. 4. Mimosa lamolina. A habit; B shoot and mature leaves; C pinna and underside of leaflet; D mucro at tip of petiole, paraphyllidia and setulae on pulvinules of pinnular rachis; E stipule on young shoot; $\mathrm{F}$ older stipule showing persistent ribs; $\mathrm{G}$ flower; $\mathrm{H}$ floral bract and longitudinal section of flower; J fruits. A - H from Hughes et al. 2648; J from Vandrot et al. 226. DRAWN BY ROSEMARY WISE. 
DISTRIBUTION. The species is known only from the type locality in the lower Río Huancabamba valley, a tributary of the Río Marañón. Map 1.

SPECIMENS EXAMINED. PERÚ. Cajamarca: Prov. Jaén, $\mathrm{km} 164$ on main rd from Olmos to Jaén, between Pucará and Chamaya in the valley of the Río Huancabamba, 555'57"S 7850'19"W, 620 m, 22 April 2007, fls., Hughes 2648, Daza, Särkinen E̋ Baden (FHO!, K!, MOL!); Prov. Jaén, km 165 on main rd from Olmos to Jaén, $5 \mathrm{~km}$ from Chiple towards Jaén, $5^{\circ} 55^{\prime} 52^{\prime \prime S}$ 78 50 '17"W, 650 m, 8 April 2008, fls., Vandrot 201, Daza, D’ugard Ẽ Särkinen (E!, FHO!, MOL!); Prov. Jaén, $5 \mathrm{~km} \mathrm{E}$ of Chiple on main rd from Olmos to Jaén, 553'52"S 7850'12"W, 650 m, 2 May 2008, fls. \& unripe fr., Vandrot 226, Daza, Särkinen E् D'ugard (holotype K!; isotypes E!, FHO!, MOL!, NY!).

HABITAT. Mimosa lamolina is apparently infrequent in disturbed seasonally dry tropical forest or dry thorn scrub; 650 m. Occurs with Acacia sp., Leucaena trichodes, Caesalpinia cassioides Willd., Senna sp., Cordia saccellia Gottschling \& J. S. Mill., Capparis scabrida Kunth, Tecoma rosifolia Kunth, Cnidoscolus sp., Ipomoea sp., Eriotheca ruizii (K. Schum.) A. Robyns and numerous Cactaceae (including species of Melocactus, Browningia and Espostoa).

PHENOLOGY. Flowering April to May, fruiting May to June. ETYMOLOGY. Mimosa lamolina is named to mark the contribution of the MOL Forest Herbarium of the Departamento de Manejo Forestal, Facultad de Ciencias Forestales, Universidad Nacional Agraria La Molina in Lima to knowledge of the woody plants of Perú.

CONSERVATION STATUS. Mimosa lamolina is known from just a single locality in a side valley on the west side of the Río Marañón, and, as currently known, is undoubtedly globally rare and is provisionally assigned a conservation rating of Critically Endangererd (CR b1). However, pending more thorough botanical survey and collection, it remains unclear just how widespread and abundant this plant is.

NOTES. Mimosa lamolina shows a number of morphological similarities to species of Barneby's (1991) subseries Lactifluae of series Mimosa, section Mimosa, including shrubby or weakly arborescent habit, a diminutive campanulate calyx to $<0.7 \mathrm{~mm}$, 1-jugate leaves, stipules with prominent ribs and 1 - 4-seeded pods which are constricted between the seed chambers. These morphological affinities are to some extent supported by preliminary phylogenetic analyses using molecular data (Simon et al., unpublished data). In these analyses $M$. lamolina is placed in a strongly supported group of Andean dry forest Mimosas, which includes several other Marañón endemic species such as M. pectinatipinna Burkart and M. ctenodes Barneby. This Andean clade is moderately supported as sister to a clade that includes the Mexican species from subseries Lactifluae in line with the morphological similarities to that group.
Of the 10 species placed in subseries Lactifluae by Barneby (1991), Mimosa lamolina is similar in habit, lack of armature and number of leaflets per pinna to the distantly allopatric $M$. deamii, a narrowly restricted endemic from Tehuantepec in southern México, but differs from that species in indumentum, M. lamolina being virtually glabrous with only scattered short setulae on petioles, pulvinules and margins of leaflets and fruits, while $M$. deamii has a harsh strigose indumentum on shoots and leaves and dense antrorsely strigose craspedia.

A number of other species of Mimosa, including M. ctenodes, M. incarum Barneby, M. montana Kunth var. sandemanii Barneby, M. pectinatipinna and $M$. aff. weberbaueri Harms, are known to occur in the upper Marañón valley in northern Perú (an area that covers mainly parts of the Departments of Cajamarca and Amazonas, but also fringes into Piura, in the lower Huancabamba valley, and La Libertad). Mimosa lamolina can be readily distinguished from these species, as well as from the potentially nearby $M$. loxensis Barneby from southern Ecuador, all of which have microphyllidious leaves with leaflets $<15 \mathrm{~mm}$ long and $<7$ mm wide, much smaller than the $22 \times 10-11 \mathrm{~mm}$ leaflets of M. lamolina. Only M. albida Humb. \& Bonpl. ex Willd. has leaflets as large as M. lamolina, but in M. albida there are only two pairs of leaflets per pinna.

\section{Acknowledgements}

We thank Carlos Reynel and Jose Luis Marcelo for ongoing support in Perú, Rosemary Wise for the Mimosa illustration, Pat Halliday for the two Caesalpinia illustrations, Terry Pennington for assistance with transport for fieldwork, Tiina Särkinen and Hervé Vandrot for seeking and collecting fruiting material of Mimosa lamolina in Perú in 2008, Toby Pennington for providing photographs and additional collections of Caesalpinia pluviosa var. maraniona, and Katherine Challis and Melanie Thomas for preparing the Latin diagnoses. Brian Schrire and an unknown reviewer provided constructive comments that improved the text. C. Hughes was supported by a Royal Society University Research Fellowship, J. Sotuyo by a Kew Latin American Research Fellowship (KLARF), and G. Lewis was partly supported by National Science Foundation grant DEB-0316375.

\section{References}

Barneby, R. C. (1991). Sensitivae Censitae. A description of the genus Mimosa L. (Mimosaceae) in the New World. Mem. New York Bot. Gard. 65: 1 - 835.

(1998). Silk Tree, Guanacaste, Monkey's Earring. A generic system for the synandrous Mimosaceae of the Americas. Part III. Calliandra. Mem. New York Bot. Gard. 74: 1 - 223. 
Bruneau, A., Mecure, M., Lewis, G. P. \& Herendeen, P. S. (2008). Phylogenetic patterns and diversification in the caesalpinioid legumes. Canad. J. Bot. 86: $697-718$.

Hensold, N. (1999). Las angiospermas endémicas del Depto. Cajamarca, Perú. Arnaldoa 6: 141 - 184.

Hughes, C. E. (2005). Four new legumes in forty-eight hours. Oxford Plant Syst. 12: $6-7$.

, Daza Yamona, A. \& Hawkins, J. A. (2003). A new palo verde (Parkinsonia - Leguminosae: Caesalpinioideae) from Peru. Kew Bull. 58: 467 - 472.

Lewis, G. P., Daza Yamona, A. \& Reynel, C. (2004). Maraniona. A new dalbergioid legume genus (Leguminosae, Papilionoideae) from Peru. Syst. Bot. 29: 366 - 374.

Lewis, G. P. (1998). Caesalpinia. A revision of the Poincianella-Erythrostemon group. Royal Botanic Gardens, Kew.

(2005). Tribe Caesalpinieae. In: G. Lewis, B. Schrire, B. Mackinder \& M. Lock (eds), Legumes of the World, pp. 127 - 161. Royal Botanic Gardens, Kew.

\& Schrire, B. D. (1995). A reappraisal of the Caesalpinia group (Caesalpinioideae: Caesalpinieae) using phylogenetic analysis. In: M. D. Crisp \& J. J. Doyle (eds), Advances in Legume Systematics, part 7: Phylogeny, pp. 41-52. Royal Botanic Gardens, Kew.

Linares-Palomino, R. (2006). Phytogeography and floristics of seasonally dry tropical forests in Peru.
In: R. T. Pennington, G. P. Lewis \& J. A. Ratter (eds), Neotropical Savannas and Seasonally Dry Forests. Plant Diversity, Biogeography and Conservation, pp. 257 - 279. CRC Press. Boca Raton, Florida, U.S.A. \& Pennington, R. T. (2007). Lista anotada de plantas leñosas en bosques estacionalmente seco del Perú - una nueva herramienta en Internet para estudios taxonómicos, ecológicos y de biodiversidad. Arnaldoa 14: 149 - 152.

Pendry, C. A. (2004). A monograph of Ruprechtia (Polygonaceae). Syst. Bot. Monogr. 67.

Simpson, B. B. (1998). A revision of Pomaria (Fabaceae) in North America. Lundellia 1: 46 - 71. (1999). A revision of Hoffmannseggia (Fabaceae) in North America. Lundellia 2: $14-54$. \& Lewis, G. P. (2003). New combinations in Pomaria (Caesalpinioideae: Leguminosae). Kew Bull. 58: 175 - 184.

\& Miao, B.-M. (1997). The circumscription of Hoffmannseggia (Fabaceae: Caesalpinioideae: Caesalpinieae) and its allies using morphological and cpDNA restriction site data. Pl. Syst. Evol. 205: 157 178.

, Larkin, L. L. \& Weeks, A. (2003). Progress towards resolving the relationships of the Caesalpinia group (Caesalpinieae: Caesalpinioideae: Leguminosae). In: B. B. Klitgaard \& A. Bruneau (eds), Advances in Legume Systematics, part 10, Higher Level Systematics, pp. 123 - 148. Royal Botanic Gardens, Kew. 